\title{
THE EFFECT OF WARM GINGER COMPRESS TOWARDS JOINT PAIN OF THE ELDERLY AT UPT PANTI WERDHA MOJOPAHIT, MOJOKERTO DISTRICT
}

\author{
Puteri Indah Dwipayanti ${ }^{1}$, Anik Supriani ${ }^{1 *}$, Nanik Nur Rosyidah ${ }^{1}$, Nurul Mufida ${ }^{1}$ \\ ${ }^{1}$ STIKES Dian Husada Mojokerto \\ *Correspondence: \\ Anik Supriani \\ Email: aniksupriani76@gmail.com
}

\begin{abstract}
Background: There was joint pain that frequently happens by the elderly, which was joint pain. One of actions to abate the joint pain was compress with warm ginger.

Objectives: The aims of this research were to identify the effect of warm ginger compress towards joint pain of the elderly at UPT Panti Werdha Mojopahit, Mojokerto District.

Method: Design of this research was Pre-Experiment with Type of one group pre-test-post test design. Population of this research was whole of elderly who undergoes joint pain at UPT Panti Werdha Mojopahit Mojokerto district. Technique that used to take sample in this research was purposive sampling with 20 respondents. Data collecting was done before and after warm ginger compress was given use pain scale instrument PAINAD with 1-10 scale. The researcher used Wilcoxon statistic test with value of $\alpha=0,05$ to analyze the data.

Results: The result of this research wasgained before carried out by warm ginger compress with advance pain scale of 6 respondents $(30 \%)$, and intermediate pain scale of 10 respondents (50\%). After the warm ginger compress was done by 8 respondents $(40 \%)$ with light pain scale and 11 respondents (55\%) with intermediate pain. Data analyzing used statistic test with Wilcoxon P value test $0,003(\alpha<0$, 05). It showed that warm ginger compress effective towards joint pain of the elderly.

Conclusion: Looking at the result above shows that warm ginger compress can be created as one of alternative choices to decrease joint pain intensity of the elderly, because this non-pharmacologist treatment uses easy to be obtained ingredient and there is no side effect for the elderly.

Key words: Joint Pain, Warm Ginger Compress, Elderly.
\end{abstract}

\section{INTRODUCTION}

Elderly people will experience the loss of the network's ability to improve or change and the ability to maintain normal functions slowly and so cannot withstand the infection and repair the damage (Constantinides,1994). Aging process usually marked by physical changes in biological, mental or psychosocial. The physical changes can be related to the musculoskeletal system, nervous system, cardiovascular system, integument system, respiratory system, endocrine system, the auditory system, vision system and urinary system. One of the changes that occurs is in the musculoskeletal system of the elderly, among others, in the joints, and includes four diseases that are closely related to the aging process and the frequent response, namely pain in the joints (Pujiastuti, 2003). Joint pain is a degenerative bone disease characterized by joint loss (Corwin, 2009). The amount of loss caused by joint pain, there are still many elderly people who do not know about the use of ginger compresses in reducing pain due to inflammation in their joints. A phenomenon that occurs in the community, the elderly only use balm, massage oil, and analgesics to reduce joint pain. By providing a warm compress of 
ginger, the elderly can avoid the risk of side effects that can damage organs (Santosa, 2016). World Health Organization (WHO) The World Health Organization states that the joint pain suffered by individuals aged over 60 years. Cases of joint pain in older adults in the world is estimated to reach $9.6 \%$ in men and $18 \%$ in women. The total pain prevalence in Indonesia was 34.3 million in 2002 and reached 36.5 million in 2007. It is estimated that $40 \%$ of the population aged over 65 years suffer from joint pain, and $80 \%$ of patients with joint pain have limited motion in varying degrees from mild to severe. Based on research conducted by Damayanti (2012), it was found that $89.5 \%$ of the total respondents experienced a decrease in pain intensity after being given warm compresses of ginger, using a ginger stew for compress ingredients. The causes of pain in the elderly are changes in connective tissue (collagen and elastin), reduced cartilage to regenerate, reduced bone density, changes in muscle structure, and decreased joint elasticity. This causes most of the elderly to experience musculoskeletal system disorders such as pain in the joints (Pujiastuti, 2003). At the joint pain usually less, comfortable circumstances would appear to be touched, appeared swelling, inflammation, stiffness, and limitation of motion. One of the non-pharmacological interventions to reduce joint pain in elderly patients is one of warm ginger compresses, because ginger contains the enzyme cyclooxygenase which can reduce inflammation in the joints. In addition, ginger also has pharmacological effects, namely hot and spicy (gingerol), which can reduce pain, stiffness and muscle spasm or the occurrence of vascular vasodilation, the maximum benefit will be achieved within 20 minutes after a warm application (Brunner \& Suddarth, 2001). The purpose of this study was to identify the effect of warm ginger compress towards joint pain of the elderly at UPT Panti Werdha Mojopahit, Mojokerto District.

\section{METHODS}

\section{Study Design}

The study used pre-experiment with type one group pre-test-post-test design.

\section{Setting}

This research was conducted in UPT Panti Werdha Mojopahit, Mojokerto District.

\section{Research Subject}

The sampling technique used in this study was purposive sampling. The study sample was all elderly who experienced joint pain in UPT Panti Werdha Mojopahit, Mojokerto District as many as 20 respondents.

\section{Instrument}

This research was carried out before being given a treatment in the form of giving warm ginger compresses, pain was measured first (pre-test). After that, treatment was carried out in the form of giving warm ginger compresses by ginger being burned, then pounded, then ginger wrapped in gauze and given $\mathrm{NaCl}$ liquid, and then affixed to the joints which experienced pain. After being given an intervention, respondents were measured for the perceived pain scale with PAINAD Scale.

\section{Data Analysis}

The results of this study were analyzed using the Wilcoxon statistic test with value of $\alpha=0,05$.

\section{RESULTS}

\section{Characteristics of Respondents by Age}

Table 1. Distribution of Frequency of Respondents by Age in the Elderly in UPT Panti Werdha Mojopahit, Mojokoerto District $(n=20)$.

\begin{tabular}{cccc}
\hline No & $\begin{array}{c}\text { Age } \\
\text { (Years) }\end{array}$ & Frequency & Percentage (\%) \\
\hline 1 & $45-59$ & 2 & 10 \\
2 & $60-74$ & 8 & 40 \\
3 & $75-90$ & 10 & 50 \\
4 & $>90$ & 0 & 0 \\
\hline & Total & 20 & 100 \\
\hline
\end{tabular}

Sources: Primary Data of Questionnaire

Based on the table 1 shows that the characteristics of respondents by age was $75-90$ years, as many as 10 respondents $(50 \%)$.

\section{Characteristics of Respondents by Level of Education}

Based on table 2, it was found that the characteristics of respondents based on level of education were mostly elementary school students, as many as 11 respondents (55\%). 
Table 2. Distribution of Frequency of Respondents by Level of Education in the Elderly in UPT Panti Werdha Mojopahit, Mojokerto District $(n=20)$.

\begin{tabular}{cccc}
\hline No & $\begin{array}{c}\text { Level of } \\
\text { Education }\end{array}$ & Frequency & $\begin{array}{c}\text { Percentage } \\
(\%)\end{array}$ \\
\hline 1 & $\begin{array}{c}\text { Elementary } \\
\text { School }\end{array}$ & 11 & 55 \\
& $\begin{array}{c}\text { Junior High } \\
\text { School }\end{array}$ & 5 & 25 \\
& Senior High & 2 & 10 \\
3 & School & 2 & 10 \\
\hline 4 & University & 20 & 100 \\
\hline & Total &
\end{tabular}

Sources: Primary Data of Questionnaire

\section{Characteristics of Respondents by Gender}

Table 3. Distribution of Frequency of Respondents by Gender in the Elderly in UPT Panti Werdha Mojopahit, Mojokerto District $(n=20)$.

\begin{tabular}{cccc}
\hline No & Gender & Frequency & Percentage (\%) \\
\hline 1 & Male & 8 & 40 \\
2 & Female & 12 & 60 \\
\hline & Total & 20 & 100 \\
\hline
\end{tabular}

Sources: Primary Data of Questionnaire

Based on table 3, it was found that the characteristics of respondents based on gender were mostly Female, as many as 12 respondents $(60 \%)$.

Examination of the Effect of Warm Ginger Compress towards Joint Pain of the Elderly at UPT Panti Werdha Mojopahit, Mojokerto District

Table 4. The Effect of Warm Ginger Compress towards Joint Pain of the Elderly at UPT Panti Werdha Mojopahit, Mojokerto District $(\mathrm{n}=20)$

\begin{tabular}{ccccc}
\hline $\begin{array}{c}\text { The Level of } \\
\text { Pain }\end{array}$ & $\begin{array}{c}\text { Before Being Given A } \\
\text { Warm Ginger } \\
\text { Compress Treatment }\end{array}$ & $\begin{array}{c}\text { After Being Given A } \\
\text { Warm Ginger } \\
\text { Compress Treatment }\end{array}$ \\
\cline { 2 - 5 } & Frequency & $\begin{array}{c}\text { Percentage } \\
(\%)\end{array}$ & Frequency & $\begin{array}{c}\text { Percentage } \\
(\%)\end{array}$ \\
\hline No Pain & 0 & 0 & 1 & 5 \\
Mild Pain & 4 & 20 & 8 & 40 \\
Moderate Pain & 10 & 50 & 11 & 55 \\
Severe Pain & 6 & 30 & 0 & 0 \\
\hline Total & 20 & 100 & 20 & 100 \\
\hline \multicolumn{5}{c}{$\mathrm{p}=0.003, \alpha<0.05$} \\
\hline Sources: Primary
\end{tabular}

Based on the results of research on the effect of ginger warm compresses on joint pain, it was found that pain before warm compresses of ginger half of the respondents experienced moderate pain 10 respondents (50\%). Meanwhile, after warm ginger compresses some respondents experienced moderate pain 11 respondents (55\%). Based on the results of the study found that $p=0.003$, because this is the $\alpha$ value $<0.05$ then $\mathrm{H} 1$ is accepted, thus there is an effect of giving warm ginger compresses to joint pain in the elderly in UPT Panti Werdha Mojopahit, Mojokerto District.

\section{DISCUSSION}

The Level of Pain Before Being Given A Warm Ginger Compress Treatment

Based on the results of this research which conducted in UPT Panti Werdha Mojopahit, Mojokerto District to 20 respondents who experienced joint pain and before being given the treatment of warm ginger compresses obtained data that half of the respondents experienced moderate pain 10 respondents $(50 \%)$. Pain is defined as a condition that affects a person and their extensions are known if someone has experienced them (Tamsuri, 2007). Perry dan Potter (2006) stated that there are several factors that influence pain, including age, education, culture, attention, anxiety, fatigue, previous experience, coping style and family and social support. One of the characteristics studied in this study is the factor of age, education and gender. In the elderly the decline in the musculoskeletal system is a progressive reduction in height, increased risk of fracture or fractures, joint pain, inflammation, decreased joint mobility, deformity, bone loss, and muscle atrophy. One of the changes that occurs is in the musculoskeletal system of the elderly, among others, in the joints, and includes four diseases that are closely related to the aging process and the frequent response, namely pain in the joints (Pujiastuti, 2003). Joint pain is a degenerative bone disease characterized by joint loss (Corwin, 2009). Pain usually occurs after a person has done an activity or activity and will disappear after resting.

The results showed that the pain experienced by respondents mostly experienced moderate pain. This happened because the respondents had never done treatment with warm ginger compress therapy and the respondents only used medical drugs or balm to overcome their joint pain, so there were times when respondents did not consume medical drugs, because they were bored. 
Respondents who consume drugs too often, such as analgesics, will adversely affect the patient, such as nausea, vomiting, and can also cause damage to the kidneys, because the kidneys cannot filter drugs that have entered the kidney. When respondents use balm to deal with pain they can also cause side effects, such as burning sensation on the skin. There are several factors that can increase joint pain in respondents, namely excessive activity and food consumption. Respondents who experienced joint pain showed grimacing facial expressions.

Based on Table 1, it was found that half of respondents aged 75-90 years were 10 respondents $(50 \%)$. Age greatly influences its tolerance to pain. This will affect changes in pain scale experienced by respondents. Age can affect pain because control of one's pain will change and differ according to age (Indonesian Ministry of Health, 1997). From the results of the study showed that the increasing age of a person there will also be a change or health problems. In the elderly aged $75-90$ years most experience changes in physical such as joint pain, can be caused by a decrease in muscle mass or because of excessive activity and lack of control food intake that can cause joint pain. Based on Table 2, it was found that most of them were elementary school education, as many as 11 respondents (50\%). According to Notoatmodjo (2003), the higher education someone is getting easier to receive information, so the more knowledge he has. From the results of the study, most of the respondents had elementary education. Knowledge that is less able to inhibit the development of a person's attitude towards new values introduced to respondents such as understanding, goals, benefits and procedures for giving warm ginger compresses. This requires a therapeutic approach and communication so that the respondent can receive the information provided.

Table 3 shows that the majority of female respondents were 12 respondents $(60 \%)$. In general, men and women do not differ significantly in response to pain (Gil, 1990). Pain tolerance has long been the subject of research involving men and women. However, tolerance to pain is influenced by biochemical factors and is unique to each individual, regardless of gender. From the results of the study most of the respondents were women.
This is because the majority of elderly people who are in the place of research are mostly female. But gender does not have a full effect on pain, because each respondent or individual has different coping mechanisms to deal with the problems that they experience, whether health problems or problems from the outside environment.

\section{The Level of Pain After Being Given A Warm Ginger Compress Treatment}

Based on table 4 it was found that after being given warm compresses ginger found most of the pain was 11 respondents (55\%). This happened because after giving warm compresses of ginger circulation in the blood smoothly and the supply of food and oxygen was better, pain could decrease or stabilize. Zingiberaceae is a group of plants that can help anyone with joint pain problems. Zingerol, gingerol, and shogaol are the ingredients of ginger which is useful for reducing joint pain. The water and oil content that evaporates in ginger serves as an enhancer that can increase oleoresin permeability through the skin without causing irritation or damage to the peripheral circulation (Izza, 2014).

A warm compress of ginger is an action that is often used as a joint pain medication because it contains gingerol and the warmth it creates makes the blood vessels open and facilitates blood circulation, so that the supply of food and oxygen is better and joint pain is reduced (Utami \& Puspaningtyas, 2013). After doing the research, it was found that most of the elderly experienced a decrease in joint pain because of ginger there was a feeling of heat and warmth that could be used to meet the comfort needs of respondents. Feeling comfortable in the respondent will make the muscles feel relaxed and reduce contractions in the muscles. However, the value of the decrease in the intensity of joint pain of respondents is different, because it can be caused by excessive activity and food consumption.

The Effect of Warm Ginger Compress towards Joint Pain of the Elderly at UPT Panti Werdha Mojopahit, Mojokerto District

Based on table 4, it can be concluded that the results of the study after warm ginger compresses for 7 days were obtained without pain 1 respondent $(5 \%)$ mild pain 8 respondents $(40 \%)$ and moderate pain 11 respondents 
$(55 \%)$. Based on the Wilcoxon test obtained the value of $p=0.003, \alpha<0.05$, which means $H 1$ is accepted, thus there is the effect of giving warm compresses (ginger) to joint pain in the elderly in UPT Panti Werdha Mojopahit, Mojokerto District.

Warm compresses of ginger can reduce joint pain, because ginger can improve control of pain. Ginger has a spicy and warm flavor (Heriana, 2009). This hot and spicy effect on ginger can reduce pain, stiffness and muscle spasm in joint pain. So that ginger can also treat diseases, ginger also has many properties such as antihelmetic, anthraxic, and colds. Ginger has the effect of reducing pain sensation as well as improving the healing process of damaged tissue, using heat in ginger in addition to providing physiological reactions, including: increasing the inflammatory response (Utami, 2005). In the physiology stage of pain, warm ginger compresses reduce joint pain at the transduction stage, where this stage ginger contains gingerol which contains cyclooxygenase which can inhibit the formation of prostaglandins as pain mediators, resulting in decreased joint pain (Izza, 2014).

From the data on the results of joint pain changes of the respondents above, it can be concluded that the decrease in joint pain in each respondent is very different, this can be triggered by several factors that affect joint pain in the elderly, both from external environmental factors and themselves. Judging from the decrease in joint pain that occurs, the administration of warm compresses of ginger indicates that there are results of changes that are quite effective against decreasing joint pain in the respondent. However, there were respondents who did not experience a decrease in pain scale, some even increased, this happened because it was influenced by several factors such as excessive activity and food consumed by respondents, besides the severity of the respondent's disease which was not only enough to be given warm ginger compress therapy in reducing joint pain in respondents. In respondents who experienced increased pain, respondents often consumed nuts, and excessive activity, without being balanced with adequate rest. Thus, non-pharmacological therapy by giving warm compresses of ginger can be used as an alternative choice to reduce the intensity of joint pain in the elderly, because this non-pharmacological therapy other than the material is easily obtained and does not cause side effects in the elderly. But it should also be noted in the therapy of giving warm ginger compresses, if too much will result in disruption of the skin, namely kemeran and blisters.

\section{CONCLUSION}

Based on the results of the study there are several things that can be concluded, among others:

1. Before being given therapy for warm ginger compress, respondents were found in the category of moderate pain 10 respondents $(50 \%)$ and severe pain 6 respondents $(30 \%)$.

2. After being given therapy for warm ginger compress, respondents were found in the category of mild pain 8 respondents $(40 \%)$ and moderate pain 11 respondents $(55 \%)$.

3. There was a decrease in the level of joint pain in the elderly in UPT Panti Werdha Mojopahit, Mojokerto District with the Wilcoxon test showed $\mathrm{p}=$ 0.003 with a significance level of $\alpha<$ 0.05 .

\section{SUGGESTION}

It is expected that there will be a policy from the orphanage in the implementation of ginger warm compress therapy for once a week and is applied to all elderly who experience joint pain, which aims to accelerate the process of reducing the level of pain. For the researchers, they can then examine the differences in the effectiveness of giving warm ginger compresses and giving warm compresses of lemongrass to joint pain in the elderly.

\section{REFERENCES}

Arikunto, S. (2010). 206. Prosedur Penelitian Suatu Pendekatan Praktik. Jakarta: PT Rineka Cipta.

Azizah, L. M. R. (2011). Keperawatan Lanjut Usia. Yogyakarta: Graha Ilmu.

Brunner \& Suddarth. (2013). Keperawatan Medikal Bedah. Jakarta: EGC.

Corwin, E. J. (2000). Buku Saku Patofisiologi. Jakarta: Buku Kedokteran EGC.

Damaiyanti, S., \& Siska, T. Y. (2014). Pengaruh Kompres Jahe Hangat Terhadap Penurunan Intensitas Nyeri Artritis 
Rhematoid Pada Lanjut Usia Di Panti Sosial Tresna Werdha Kasih Sayang Ibu Kanagarian Cubadak Batu Sangkar 2012. 'AFIYAH, 1(2).

Fauzi, Arif. (2017). Aneka Tanaman Obat dan Khasiatnya. Yogyakarta: Media Pressindo.

Hamid, A. Y. S. (2007). Riset Keperawatan: Konsep, Etika dan Instrumentasi. Jakarta: EGC.

Heriana, Arif. (2009). Tumbuhan Obat dan Khasiatnya. Seri I. Jakarta: Penebar Swadaya.

Hidayat, A., Aziz. (2012). Pengantar Kebutuhan Dasar Manusia - Aplikasi Konsep dan Proses Keperawatan, Edisi 2. Jakarta: Salemba Medika.

Izza, S. (2014). Perbedaan Efektifitas Pemberian Kompres Air Hangat dan Pemberian Kompres Jahe Terhadap Penurunan Nyeri Sendi pada Lansia di Unit Rehabilitasi Sosial Wening Wardoyo Ungaran. Skripsi: STIKES Ngudi Waluyo Ungaran.

Mansjoer, A. (2000). Kapita Selekta Kedokteran. Jakarta: Media Aesculapius.

Mubarak, W. I., Indrawati, L., \& Susanto, J. (2015). Buku Ajar Ilmu Keperawatan Dasar. Jakarta: Salemba Medika.

Mujahidullah, K. (2012). Keperawatan Geriatrik. Yogyakarta: Pustaka Pelajar.

Notoatmodjo, S. (2010). Metodologi Penelitian Kesehatan. Jakarta: Rineka Cipta.

Nugroho, H. Wahyudi. (2000). Keperawatan Gerontik 2 Geriatrik Edisi 3. Jakarta: EGC.

Nursalam. (2016). Metodologi Penelitian Ilmu Keperawatan : Pendekatan Praktis. Jakarta: Salemba Medika.

Perry, A. G., \& Potter, P. A. (2005). Buku Ajar Fundamental Keperawatan: Konsep, Proses Dan Praktik. Jakarta: EGC.

Pudjiastuti, S. S., \& Utomo, B. (2003). Fisioterapi Pada Lansia. Jakarta: EGC.

Stanley, M., \& Beare, P. G. (2006). Buku Ajar Keperawatan Gerontik. Jakarta: EGC.

Sunaryo, W. Rahayu. (2016). Asuhan Keperawatan Gerontik. Yogyakarta: ANDI.

Utami, dkk. (2005). Tanaman Obat untuk Mengatasi Nyeri Rematik dan Asam Urat. Jakarta: ECG.
Cite This Article As: Dwipayanti, P. I., Supriani, A., Rosyidah, N. N., \& Mufida, N. The Effect of Warm Ginger Compress towards Joint Pain of the Elderly at UPT Panti Werdha Mojopahit, Mojokerto District. Nurse and Health: Jurnal Keperawatan 2018; 7(2): 100-105. 